\title{
International Publications of Authors from Bosnia and Herzegovina in Current Contents Indexed Publications in the Second Half of $2017^{*}$
}

Adler G, Adler MA, Urbańska A, Skonieczna-Żydecka K, Kiseljakovic E, Valjevac A, et al. Bosnian study of APOE distribution (BOSAD): a comparison with other European populations. Ann Hum Biol. 2017 Sep;44(6):568-573. doi: 10.1080/03014460.2017.1346708. Epub 2017 Jul 13.

Anisovich AV, Burkert V, Hadžimehmedović M, Ireland DG, Klempt E, Nikonov VA, et al. Strong Evidence for Nucleon Resonances near $1900 \mathrm{MeV}$. Phys Rev Lett. 2017 Aug 11;119(6):062004. doi: 10.1103/PhysRevLett.119.062004. Epub 2017 Aug 11.

Avdibegović E, Hasanović M. The Stigma of Mental Illness and Recovery. Psychiatr Danub. 2017 Dec;29(Suppl 5):900905.

Babić D, Babić R, Vasilj I, Avdibegović E.Stigmatization of Mentally Ill Patients through Media. Psychiatr Danub. 2017 Dec;29(Suppl 5):885-889.

Barišić T, Pecirep A, Milićević R, Vasilj A, Tirić D. What do pregnant women know about harmful effects of medication and herbal remedies use during pregnancy? Psychiatr Danub. 2017 Dec;29 Suppl 4(Suppl 4):804-811.

Bebek-Ivanković H, Grgić S, Curić I, Nikolić J. Socioeconomics Conditionality of Seroprevalence of Hepatitis a in Three South-West Cantons of the Federation of Bosnia and Herzegovina. Psychiatr Danub. 2017 Dec;29 Suppl 4(Suppl 4):816-822.

Bejdić P, Avdić R, Amidžić L, Ćutahija V, Tandir F, Hadžiomerović N, et al. Ultrastructure of plasma cells in harderian gland of laying hens. Anat Histol Embryol. 2018 Feb;47(1):46-50. doi: 10.1111/ahe.12322. Epub 2017 Nov 19

Bektašević M, Carev I, Roje M, Jurin M, Politeo O. Phytochemical Composition and Antioxidant Activities of the Essential Oil and Extracts of Satureja subspicata Vis. Growing in Bosnia and Herzegovina. Chem Biodivers. 2017 Oct;14(10). doi: 10.1002/cbdv.201700239. Epub 2017 Sep 30.

Bevanda DG, Čačić M, Mihaljević S, Bevanda M, Bogut A, Karin M. Allergic reactions and anesthesia. Psychiatr Danub. 2017 Dec;29 Suppl 4(Suppl 4):778-786.

Bjelanović V, Raguž MJ, Galić M, Čuljak A, Bjelanović I, Tomić V. Perinatal complications in two cohort groups of preterm newborns in Intensive care unit for Children's Diseases of University Clinical Hospital Mostar. Psychiatr Danub. 2017 Dec;29 Suppl 4(Suppl 4):812-815.
Bozovic I, Kacar A, Peric S, Nikolic A, Bjelica B, Cobeljic $\mathrm{M}$, et al. Quality of life predictors in patients with chronic inflammatory demyelinating olyradiculoneuropathy. J Neurol. 2017 Dec;264(12):2481-2486. doi: 10.1007/s00415017-8658-x. Epub 2017 Oct 30

Bravo-Mehmedbašić A, Kučukalić S. Stigma of psychiatric diseases and psychiatry. Psychiatr Danub. 2017 Dec;29(Suppl 5):877-879.

Costa FA, Scullin C, Al-Taani G, Hawwa AF, Anderson C, Bezverhni Z, et al. Provision of pharmaceutical care by community pharmacists across Europe: Is it developing and spreading? J Eval Clin Pract. 2017 Dec;23(6):1336-1347. doi: 10.1111/jep.12783. Epub 2017 Aug 1.

Cristea S, Smits A, Kulo A, Knibbe CAJ, van Weissenbruch M, Krekels EHJ, et al. Amikacin Pharmacokinetics To Optimize Dosing in Neonates with Perinatal Asphyxia Treated with Hypothermia. Antimicrob Agents Chemother. 2017 Nov 22;61(12). pii: e01282-17. doi: 10.1128/ AAC.01282-17. Print 2017 Dec.

Coralić A, Gabrielli S, Zahirović A, Stojanović NM, Milardi GL, Jažić A, et al. First molecular detection of Babesia canis in dogs from Bosnia and Herzegovina. Ticks Tick Borne Dis. 2018 Feb;9(2):363-368. doi: 10.1016/j. ttbdis.2017.11.013. Epub 2017 Dec 24.

Delibegović S, Mehmedovic Z. The influence of the different forms of appendix base closure on patient outcome in laparoscopic appendectomy: a randomized trial. Surg Endosc. 2018 May;32(5):2295-2299. doi: 10.1007/s00464017-5924-z. Epub 2017 Nov 2.

Dimitrova N, Znaor A, Agius D, Eser S, Sekerija M, Ryzhov $A$, et al. Breast cancer in South-Eastern European countries since 2000: Rising incidence and decreasing mortality at young and middle ages. Eur J Cancer. 2017 Sep;83:43-55. doi: 10.1016/j.ejca.2017.06.011. Epub 2017 Jul 14.

Fadilpašić S, Maleč D, Džubur-Kulenović A. Relationship of Religiousness and Religious Coping with Quality of Life among War Trauma Survivors. Psychiatr Danub. 2017 Sep;29(3):291-301. doi: 10.24869/psyd.2017.291.

Fajkić A, Musić M, Kulenović AD, Začiragić A, Avdagić N, Babić N, et al. Elevated Serum C-Reactive Protein Level Is not Associated with Serum Nitric Oxide in Patients with

${ }^{\star}$ Data for this survey were collected from PubMed/MEDLINE using the keywords Bosnia and Herzegovina and 2017. The search was performed on the $21^{\text {st }}$ of May 2018. 
Posttraumatic Stress Disorder. Psychiatr Danub. 2017 Dec;29(4):431-436. doi: 10.24869/psyd.2017.431.

Ferrario A, Arāja D, Bochenek T, Čatić T, Dankó D, Dimitrova M, et al. The Implementation of Managed Entry Agreements in Central and Eastern Europe: Findings and Implications. Pharmacoeconomics. 2017 Dec;35(12):12711285. doi: 10.1007/s40273-017-0559-4.

Figurek A, Spasovski G, Popovic-Pejicic S. FGF23 Level and Intima-Media Thickness Are Elevated From Early Stages of Chronic Kidney Disease. Ther Apher Dial. 2018 Feb;22(1):40-48. doi: 10.1111/1744-9987.12592. Epub 2017 Oct 3 .

Glusac J, Isaschar-Ovdat S, Kukavica B, Fishman A. Oil-inwater emulsions stabilized by tyrosinase-crosslinked potato protein. Food Res Int. 2017 Oct;100(Pt 1):407-415. doi: 10.1016/j.foodres.2017.07.034. Epub 2017 Jul 17.

Grgurevic I, Bokun T, Salkic NN, Brkljacic B, VukelićMarkovic M, Stoos-Veic T, et al. Liver elastography malignancy prediction score for noninvasive characterization of focal liver lesions. Liver Int. 2018 Jun;38(6):1055-1063. doi: 10.1111/liv.13611. Epub 2017 Nov 3.

Gurbeta L, Dzemic Z, Bego T, Sejdic E, Badnjevic A. Testing of Anesthesia Machines and Defibrillators in Healthcare Institutions. J Med Syst. 2017 Sep;41(9):133. doi: 10.1007/ s10916-017-0783-7. Epub 2017 Jul 27.

Hadzic E, Sinanovic O, Memisevic H. Is Bacterial Meningitis a Risk Factor for Developing Attention Deficit Hyperactivity Disorder. Isr J Psychiatry Relat Sci. 2017;54(2):54-57.

Horvat O, Popržen J, Tomas A, Paut Kusturica M, Tomić Z, Sabo A. Factors associated with non-adherence among type 2 diabetic patients in primary care setting in eastern Bosnia and Herzegovina. Prim Care Diabetes. 2018 Apr;12(2):147154. doi: 10.1016/j.pcd.2017.10.002. Epub 2017 Oct 28.

Hukić M, Seljmo D, Ramovic A, Ibrišimović MA, Dogan S, Hukic J, et al. The Effect of Lysozyme on Reducing Biofilms by Staphylococcus aureus, Pseudomonas aeruginosa, and Gardnerella vaginalis: An In Vitro Examination. Microb Drug Resist. 2018 May;24(4):353-358. doi: 10.1089/ mdr.2016.0303. Epub 2017 Sep 18.

Ibrahimagić OĆ, Smajlović D, Dostović Z, Mujagić S, Pašić Z, Salihović D.Change of the Writing-Hand: Unusual Manifestation of Hallervorden-Spatz Disease. Psychiatr Danub. 2017 Dec;29(4):507-509. doi: 10.24869/ psyd.2017.507.

Imamovic D, Vranic S. Novel regulators of PD-L1 expression in cancer: CMTM6 and CMTM4-a new avenue to enhance the therapeutic benefits of immune checkpoint inhibitors. Ann Transl Med. 2017 Dec;5(23):467. doi: 10.21037/atm.2017.09.32.

Janković J, Šiljak S, Erić M, Marinković J, Janković S. Inequalities in the utilization of health care services in a transition European country: results from the national population health survey. Int J Public Health. 2018 Mar;63(2):261-272. doi: 10.1007/s00038-017-1009-y. Epub 2017 Jul 14.
Jurišić D, Geber MZ, Ćavar I, Utrobičić DK. Retinal Layers Measurements following Silicone Oil Tamponade for Retinal Detachment Surgery. Semin Ophthalmol. 2017 Dec 19:1-8. doi: 10.1080/08820538.2017.1417452. [Epub ahead of print]

Karabuva S, Lukšić B, Brizić I, Latinović Z, Leonardi A, Križaj I. Ammodytin L is the main cardiotoxic component of the Vipera ammodytes ammodytes venom. Toxicon. 2017 Dec 1;139:94-100. doi: 10.1016/j.toxicon.2017.10.003. Epub 2017 Oct 10

Kardum V, Karin V, Glibo M, Skrtic A, Martic TN, Ibisevic $\mathrm{N}$, et al. Methylation-associated silencing of SFRP1 gene in high-grade serous ovarian carcinomas. Ann Diagn Pathol. 2017 Dec;31:45-49. doi: 10.1016/j.anndiagpath.2017.07.002. Epub 2017 Jul 15.

Kasum M, Orešković S, Čehić E, Lila A, Ejubović E, Soldo D. The role of female obesity on in vitro fertilization outcomes. Gynecol Endocrinol. 2018 Mar;34(3):184-188. doi: 10.1080/09513590.2017.1391209. Epub 2017 Oct 16 .

Klarić M, Lovrić S. Methods to Fight Mental Illness Stigma. Psychiatr Danub. 2017 Dec;29(Suppl 5):910-917.

Kučukalić S, Kučukalić A. Stigma and Suicide. Psychiatr Danub. 2017 Dec;29(Suppl 5):895-899.

Leblebicioglu H, Arends JE, Ozaras R, Corti G, Santos L, Boesecke C, et al. Availability of hepatitis $\mathrm{C}$ diagnostics and therapeutics in European and Eurasia countries. Antiviral Res. 2018 Feb;150:9-14. doi: 10.1016/j.antiviral.2017.12.001. Epub 2017 Dec 5

Lekic A, Brekalo Z, Kvesic A, Kovacevic M, BaricevNovakovic Z, Sutic I, et al. Crosstalk Between Enzyme Matrix Metalloproteinases 2 and 9 and Regulatory T Cell Immunity in the Global Burden of Atherosclerosis. Scand J Immunol. 2017 Jul;86(1):65-71. doi: 10.1111/sji.12563.

Liu J, van Klinken JB, Semiz S, van Dijk KW, Verhoeven A, Hankemeier T, et al. A Mendelian Randomization Study of Metabolite Profiles, Fasting Glucose, and Type 2 Diabetes. Diabetes. 2017 Nov;66(11):2915-2926. doi: 10.2337/db170199. Epub 2017 Aug 28.

Lorenzoni G, Umihanić S, Azzolina D, Manza E, Brkić F, Gregori D. A novel approach for comparing patterns of foreign body injuries across countries: A case study comparing European Countries and Bosnia and Herzegovina. Int J Pediatr Otorhinolaryngol. 2018 Feb;105:90-96. doi: 10.1016/j.ijporl.2017.12.005. Epub 2017 Dec 7.

Madi M, Pavlic V, Samy W, Alagl A. The anti-inflammatory effect of locally delivered nano-doxycycline gel in therapy of chronic periodontitis. Acta Odontol Scand. 2018 Jan;76(1):71-76. doi: 10.1080/00016357.2017.1385096. Epub 2017 Sep 29.

Mandic A, Cavar I, Skoro I, Tomic I, Ljubic K, Coric S, et al. Body Composition and Inflammation in Hemodialysis Patients. Ther Apher Dial. 2017 Dec;21(6):556-564. doi: 10.1111/1744-9987.12575. Epub 2017 Sep 22.

Marasovic M, Ivankovic S, Stojkovic R, Djermic D, Galic B, Milos M. In vitro and in vivo antitumour effects of phenylboronic acid against mouse mammary adenocarcinoma 4T1 and squamous carcinoma SCCVII 
cells. J Enzyme Inhib Med Chem. 2017 Dec;32(1):12991304. doi: 10.1080/14756366.2017.1384823.

Marijanović I, Pavleković G, Buhovac T, Martinac M. The relationship between health locus of control, depression, and sociodemographic factors and amount of time breast cancer patients wait before seeking diagnosis and treatment. Psychiatr Danub. 2017 Sep;29(3):330-344. doi: 10.24869/ psyd.2017.330.

Markotic F, Jurisic D, Curkovic M, Puljiz M, Novinscak $\mathrm{M}$, Bonassin $\mathrm{K}$, et al. Sharing of prescription analgesics amongst patients in family practice: Frequency and associated factors. Eur J Pain. 2018 Apr;22(4):716-727. doi: 10.1002/ejp.1157. Epub 2017 Dec 1

Markotić V, Zubac D, Miljko M, Šimić G, Zalihić A, Bogdan $\mathrm{G}$, et al. Level of Education as a Risk Factor for Extensive Prevalence of Cervical Intervertebral Disc Degenerative Changes and Chronic Neck Pain. Cent Eur J Public Health. 2017 Sep;25(3):245-250. doi: 10.21101/cejph.a4897.

Marković JP, Jović MD, Smičiklas ID, Šljivić-Ivanović MZ, Smiljanić SN, Onjia AE, et al. Estimation of Cadmium uptake by tobacco plants from laboratory leaching tests. J Environ Sci Health A Tox Hazard Subst Environ Eng. 2018 Mar 21;53(4):352-361. doi: 10.1080/10934529.2017.1401396. Epub 2017 Dec 27.

Medici A, Meccariello L, Rollo G, De Nigris G, Mccabe SJ, Grubor P, et al. Does routine carpal tunnel release during fixation of distal radius fractures improve outcomes? Injury. 2017 Oct;48 Suppl 3:S30-S33. doi: 10.1016/S00201383(17)30654-X

Mesic A, Markocic E, Rogar M, Juvan R, Hudler P, Komel R. Single nucleotide polymorphisms rs911160 in AURKA and rs2289590 in AURKB mitotic checkpoint genes contribute to gastric cancer susceptibility. Environ Mol Mutagen. 2017 Dec;58(9):701-711. doi: 10.1002/em.22129. Epub 2017 Aug 26.

Mikačić M, Vasilj I, Vasilj M, Bevanda D, Šimović M, Galić K. Tumor Marker CA 125 in the Diagnosis of Active Pulmonary Tuberculosis - A Study of Adults in Mostar, B\&H. Psychiatr Danub. 2017 Dec;29 Suppl 4(Suppl 4):841844.

Misceo GF, Jones MD. Touch Precision Modulates Visual Bias. J Mot Behav. 2018 May-Jun;50(3):307-311. doi: 10.1080/00222895.2017.1341381. Epub 2017 Aug 29.

Mrugała A, Šanda R, Petrusek A, Marić D, Vukić J. Recent acute crayfish mortality reveals Aphanomyces astaci presence in Bosnia and Herzegovina. J Invertebr Pathol. 2017 Nov;150:73-75. doi: 10.1016/j.jip.2017.09.004. Epub 2017 Sep 6.

Mühleisen TW, Reinbold CS, Forstner AJ, Abramova LI, Alda M, Babadjanova G, et al. Gene set enrichment analysis and expression pattern exploration implicate an involvement of neurodevelopmental processes in bipolar disorder. J Affect Disord. 2018 Mar 1;228:20-25. doi: 10.1016/j.jad.2017.11.068. Epub 2017 Nov 14.

Naletilić M, Tomić V, Ostojić L, Damjanović VM, Grabovac M. Personality traits and quality of life of mothers who have children with cerebral palsy. Psychiatr Danub. 2017 Dec;29 Suppl 4(Suppl 4):793-803.
Obradovic B. Neck Surgery Under Local Anesthesia. J Craniofac Surg. 2017 Nov;28(8):e773-e775. doi: 10.1097/ SCS.0000000000003971.

Obradovic B. Surgical Treatment as a First Option of the Lower Eyelid Xanthelasma. J Craniofac Surg. 2017 Oct;28(7):e678-e679. doi: 10.1097/SCS.0000000000003830.

Oluić J, Nikolic K, Vucicevic J, Gagic Z, Filipic S, Agbaba D. 3D-QSAR, Virtual Screening, Docking and Design of Dual PI3K/mTOR Inhibitors with Enhanced Antiproliferative Activity. Comb Chem High Throughput Screen. 2017 Aug 10;20(4):292-303. doi: 10.2174/1386207320666170427143858

Ostojić J, Herenda S, Bešić Z, Miloš M, Galić B. Advantages of an Electrochemical Method Compared to the Spectrophotometric Kinetic Study of Peroxidase Inhibition by Boroxine Derivative. Molecules. 2017 Jul 5;22(7). pii: E1120. doi: 10.3390/molecules22071120.

Pajević I, Hasanović M. Antipsychiatry as the Stigma. Psychiatr Danub. 2017 Dec;29(Suppl 5):890-894.

Pajević I, Sinanović O, Hasanović M. Association of Islamic Prayer with Psychological Stability in Bosnian War Veterans. J Relig Health. 2017 Dec;56(6):2317-2329. doi: 10.1007/ s10943-017-0431-z.

Pantic I, Milanovic A, Loboda B, Błachnio A, Przepiorka A, Nesic D, et al. Association between physiological oscillations in self-esteem, narcissism and internet addiction: A crosssectional study. Psychiatry Res. 2017 Dec;258:239-243. doi: 10.1016/j.psychres.2017.08.044. Epub 2017 Aug 19.

Pavlic V, Brkic Z, Marin S, Cicmil S, Gojkov-Vukelic M, Aoki A. Gingival melanin depigmentation by Er:YAG laser: A literature review. J Cosmet Laser Ther. 2018 Apr;20(2):85-90. doi: 10.1080/14764172.2017.1376092. Epub 2017 Nov 29

Peric R, Meucci M, Bourdon PC, Nikolovski Z. Does the aerobic threshold correlate with the maximal fat oxidation rate in short stage treadmill tests? J Sports Med Phys Fitness. 2017 Jul 25. doi: 10.23736/S0022-4707.17.07555-7. [Epub ahead of print]

Petrović T, Uzunović S, Barišić I, Luxner J, Grisold A, Zarfel $\mathrm{G}$, et al. Arrival of carbapenem-hydrolyzing-oxacillinases in Acinetobacter baumannii in Bosnia and Herzegovina. Infect Genet Evol. 2018 Mar;58:192-198. doi: 10.1016/j. meegid.2017.12.021. Epub 2017 Dec 22.

Pinto da Costa M, Giurgiuca A, Holmes K, Biskup E, Mogren T, Tomori S, et al. To which countries do European psychiatric trainees want to move to and why? Eur Psychiatry. 2017 Sep;45:174-181. doi: 10.1016/j. eurpsy.2017.06.010. Epub 2017 Jul 10.

Potpara TS, Trendafilova E, Dan GA, Goda A, Kusljugic Z, Manola S, et al. The Patterns of Non-vitamin K Antagonist Oral Anticoagulants (NOACs) Use in Patients with Atrial Fibrillation in Seven Balkan Countries: a Report from the BALKAN-AF Survey. Adv Ther. 2017 Aug;34(8):2043-2057. doi: 10.1007/s12325-017-0589-5. Epub 2017 Aug 9.

Racic M, Pekez-Pavlisko T, Jokovic S. Barriers and facilitators for implementation of family medicine-oriented model of primary care in Bosnia and Herzegovina: A qualitative study. Int J Health Plann Manage. 2018 
Jan;33(1):e378-e390. doi: 10.1002/hpm.2470. Epub 2017 Oct 5 .

Radmanović MB, Burgić S. Stigma and Mental Disorders in Developmental Age. Psychiatr Danub. 2017 Dec;29(Suppl 5):906-909.

Raguz MJ, Brzica J, Grgic I. Palivizumab: The Effects of Prophylactic Immunization on the Occurrence of Infections Caused by the Respiratory Syncytial Virus. Klin Padiatr. 2017 Sep;229(5):281-285. doi: 10.1055/s-0043-112499. Epub 2017 Sep 25.

Rastovic P, Gojanovic MD, Berberovic M, Pavlovic M, Lesko J, Galic G, et al. Isometric muscle fatigue of the paravertebral and upper extremity muscles after whiplash injury. Ann Saudi Med. 2017 Jul-Aug;37(4):297-307. doi: 10.5144/0256-4947.2017.297.

Ristić V, Maksin M, Nenković-Riznić M, Basarić J. Land-use evaluation for sustainable construction in a protected area: A case of Sara mountain national park. J Environ Manage. 2018 Jan 15;206:430-445. doi: 10.1016/j. jenvman.2017.09.080. Epub 2017 Dec 7.

Sartelli M, Weber DG, Ruppé E, Bassetti M, Wright BJ, Ansaloni L, et al. Erratum to: Antimicrobials: a global alliance for optimizing their rational use in intra-abdominal infections (AGORA). World J Emerg Surg. 2017 Aug 2;12:35. doi: 10.1186/s13017-017-0147-0. eCollection 2017.

Singh TD, O’Horo JC, Gajic O, Sakusic A, Day CN, Mandrekar J, et al. Risk factors and outcomes of critically ill patients with acute brain failure: A novel end point. J Crit Care. 2018 Feb;43:42-47. doi: 10.1016/j.jcrc.2017.08.028. Epub 2017 Aug 18.

Smolen JS, Choe JY, Prodanovic N, Niebrzydowski J, Staykov I, Dokoupilova E, et al. Comparing biosimilar SB2 with reference infliximab after 54 weeks of a double-blind trial: clinical, structural and safety results. Rheumatology (Oxford). 2017 Oct 1;56(10):1771-1779. doi: 10.1093/ rheumatology/kex254.

Smolen JS, Choe JY, Prodanovic N, Niebrzydowski J, Staykov I, Dokoupilova E, et al. Safety, immunogenicity and efficacy after switching from reference infliximab to biosimilar SB2 compared with continuing reference infliximab and SB2 in patients with rheumatoid arthritis: results of a randomised, double-blind, phase III transition study. Ann Rheum Dis. 2018 Feb;77(2):234-240. doi: 10.1136/annrheumdis-2017-211741. Epub 2017 Oct 17.

Sutovic A. Psychiatry between Glorification and Stigmatization. Psychiatr Danub. 2017 Dec;29(Suppl 5):880884 .

Špirić Z, Eri Ž, Erić M. Lymphatic vessel density and VEGF-C expression as independent predictors of melanoma metastases. J Plast Reconstr Aesthet Surg. 2017 Nov;70(11):1653-1659. doi: 10.1016/j.bjps.2017.06.040. Epub 2017 Jul 8.
Vlatkovic S, Sagud M, Svob Strac D, Sviben M, Zivkovic M, Vilibic M, et al. Increased prevalence of Toxoplasma gondii seropositivity in patients with treatment-resistant schizophrenia. Schizophr Res. 2018 Mar;193:480-481. doi: 10.1016/j.schres.2017.08.006. Epub 2017 Aug 9.

Wilke A, Bollmann U, Cazzaniga S, Hübner A, John SM, Karadzinska-Bislimovska J, et al. The implementation of knowledge dissemination in the prevention of occupational skin diseases. J Eur Acad Dermatol Venereol. 2018 Mar;32(3):449-458. doi: 10.1111/jdv.14653. Epub 2017 Nov 22.

Willer Gold J, Arsenijević B, Batinić M, Becker M, Čordalija N, Kresić M, et al. When linearity prevails over hierarchy in syntax. Proc Natl Acad Sci U S A. 2018 Jan 16;115(3):495500. doi: 10.1073/pnas.1712729115. Epub 2017 Dec 29.

Zerem E. The ranking of scientists based on scientific publications assessment. J Biomed Inform. 2017 Nov;75:107-109. doi: 10.1016/j.jbi.2017.10.007. Epub 2017 Oct 12 .

Zerem E, Jovanović P, Omerović M, Jahić D, Zerem D, Zerem O. Is Transcutaneous Endoscopic Necrosectomy Appropriate Method In Managing All Patients With Walledoff Pancreatic Necrosis That Extend Into the Paracolic Gutter. J Clin Gastroenterol. 2017 Aug 30. doi: 10.1097/ MCG.0000000000000920. [Epub ahead of print]

Zmijanac Partl J, Karin V, Skrtic A, Nikuseva-Martic T, Serman A, Mlinarec J, et al. Negative regulators of Wnt signaling pathway SFRP1 and SFRP3 expression in preterm and term pathologic placentas. J Matern Fetal Neonatal Med. 2017 Aug 7:1-9. doi: 10.1080/14767058.2017.1359830. [Epub ahead of print]

Zukić F, Miljko M, Vegar-Zubović S, Behmen A, Arapović AK. Prevalence of Coronary artery anomalies detected by Coronary CT Angiography in Canton Sarajevo, Bosnia and Herzegovina. Psychiatr Danub. 2017 Dec;29 Suppl 4(Suppl 4):830-834.

Zvan M, Zenic N, Sekulic D, Cubela M, Lesnik B. Genderand Sport-Specific Associations Between Religiousness and Doping Behavior in High-Level Team Sports. J Relig Health. 2017 Aug;56(4):1348-1360. doi: 10.1007/s10943-016-0254-3.

Zvorničanin J, Zvorničanin E. Prefoveal floaters as a differential diagnosis to optic neuritis: "mouches dormantes". Acta Neurol Belg. 2017 Oct 16. doi: 10.1007/ s13760-017-0848-x. [Epub ahead of print]

Zvorničanin J, Zvorničanin E. Re: Evaluation of posterior vitreous detachment after uneventful phacoemulsification surgery by optical coherence tomography and ultrasonography. Clin Exp Optom. 2017 Nov;100(6):736737. doi: 10.1111/cxo.12608. Epub 2017 Oct 3.

by Nerma Tanović 